\title{
Modernization of Agriculture and The Monetization of A Village Economy In Deccan Maharashtra, India
}

\section{Hemalata Dandekar}

The focus of everyday life in sugao revolves around farming. village activity changes with the agricultural season and farm tasks are the rotating pivot around which village society is organized. The agricultural cycle has traditionally been geared, in the sugao farmer's mind, to the moon and the astrological sign (of which there are twenty-seven in the Hindu calendar) in dominance at the time. In practice, cultivation tasks have become associated with phases of the Hindu lunar calendar which give the farmer guidance when to do what in his fields.

This paper describes some of the changes that have occurred in agricultural production in sugao since 1942. The intent is to illustrate, with this case study of a village microcosm, some of the forces that have been set in motion by a combination of development strategies introduced during the post-Independence decades of development planning in India. Some of these have had as a goal the fostering of urban, industrial development, others of improving the health and education of people, still others, and most importantly for sugao, of subsidizing and modernizing agriculture and inducing a shift to more cash-crop production. These strategies have had obvious and subtle effects on the Sugao economy and affected segments of the sugao society in different ways.

This paper documents, quantitatively as well as qualitatively, some of the changes that have occurred in the practice of agriculture in sugao and their impacts on village peoples' work and the village economy. The paper concludes with some conjectures about the future of development in villages like sugao if this observed direction of change is maintained.

\section{BACKGROTNND}

Sugao is a rather typical village for its region. Located in Satara District, some ten or eleven miles from wai, the nearest market town, it is two and a half miles from the Poona-Bangalore highway. The connecting approach road from the highway to sugao is no better than an all-weather cart track, negotiable by tractors and other heavy-goods transport but not by motor cars. As such, road access to the village is not unusually good nor very bad for this region of the Deccan Plateau. In terms of population, Sugao falls in the middle third of villages in the district. There were 2,583 people in residence in sugao in

SOUTH ASTA BULLE'TIN,

Vol. III No. 2

Fall 1983.
1977, at the time the last full census survey of the village was completed by the author.

The development decades in India brought with them, hand in hand with better health care and modern medicine, unusually high rates of population increase. Sugao's resident population, however, increased onIy from 1,621 in 1942 to 2,583 in 1977 (1.8\% per annum), a much slower growth rate than that of Maharashtra state where population has grown at over 2.4\% per annum since 1951. This is primarily due to migration because so many Sugao men have moved to Bombay over 150 miles away, to work mainly in industries there, so that by 1977 there were almost as many sugao men earning a living outside the village as living in the village itself.

But the population increase that did occur led to decreasing land-to-man ratios 
in the village. Whereas in 1942 there were .54 hectares (1.34 acres) of land (unadjusted for irrigated and nonirrigated) for every person in the village, by 1948 there were only .43 hectares (1.06 acres), and by 1977 this had shrunk to .34 hectares (.84 acres). It was not possible to increase the amount of land available for farming in sugao because, for the past 150 years, pasture lands had been slowly converted to farms and most marginal land that could be brought under the plough had already been.

At the present level of development in the village, sugao farms can no longer fully support even those residents who remajt in Sugao. Furthermore, those who do stay in the village have little choice about how to support themselves. The rural economy has not diversified greatly and farming one's own land or working as hired labor on someone else's farm is the major occupation in the village. This is clear from Table 1 which gives the main occupations of Sugao workers since 1942 . Despite the decreasing Iand/man ratios, nore sugao workers were employed in this sector. BY 1977 this had grown to 908, an increase not merely in relative importance but in real terms, the numbers of workers going up from 673 to 1,165 .

The fact of the matter is that most farms in Sugao are not large or fertile enough to support the farm family fully. This too is typical of this region of the Deccan plateau. Faced with this reality, Sugao farmers, like those in other villages in Satara District, have had two options: (1) remain in the village and augment income from their subsistence farms with locally available work or (2) migrate. In 1977 almost $50 \%$ of the village men lived outside sugao but maintained their families and households within the village. As a result, as enumerated in Table 2, out of a total of 399 landowning farm families, 75 (19\%) had no men living in the village and another 22 farms belonged to women who were alone. Thus 97 (or 25\%) Sugao farms were cultivated primarily by women.

Because of the traditional land distribution pattern under the ryotwari system, and the social control exerted over landownership, most of those working in agrifulture in sugao are owner-cultivators. over the years land has been divided and subdivided among family members so that, in 1977,399 of the 493 families owned land. Table 3 , which gives the size of land holdings, shows that many of these holdings are miniscule and the owners virtually landless. However, even those with tiny parcels of land cultivate them diligently, both because the land is ancestral and sacred, and also because it is usually the only asset that will provide them some security in their old age. Although there is a substantial migration of people out of the village, it is a cyclical migration for the duration of the most productive work-life of the individual. Families retain their claims to even tiny fragments of land and return to the village in their old age. Thus very little land is released and available for consolidation into larger farms more suited for extensive mechanization of the kind developed for farms in the united States.

\section{NATURE OF FAFMENG IN SUGAO IN 1942}

In 1942 most farming in sugao was subsistence farming. That is, cultivation was primarily for family consumption. The farms were operated mainly by the family members who provided the bulk of the needed labor, augmented by reciprocal work-sharing arrangements between landowning families. Thus to own land in Sugao was to have some assurance of work and a livelihood. A farm business survey by the Gokhale Institute in 1938 calculated that, of the total workdays put into agriculture, 65 \% were contributed by family labor, $15 \%$ by mutual exchange between land-owning families, and only $20 \%$ by hired labor which was employed on a casual basis mainly to meet peak-season workload.

Agriculture was primarily dependent on rainfall which in the mawal region where sugao is located is generally sufficient for a good kharif crop. (The kharif season is the main growing season in winter following the monsoon rains.) Only about 15\% of the land was irrigated 
by small earthen dams across the stream. A good monsoon rain was therefore critical. and the first rains were awaited with bated breath, the monsoon making the difference between survival and starvation for those subsisting solely on their farms. Soils in sugao are of three main types: medium to deep black soils found on river and stream banks, which are rich and suitable for garden crops; malran or lighter soils suitable for bajra (a variety of millet); and red or laterite soils which are best for rice or fruit. Soil type along with availability of water detemined the mix of crops cultivated in the village.

In 1942 bajra, interspersed with pulses, which matured and were harvested earlier, were the main kharif crop of the village (Table 4). Wheat, gram, indigenous jowar, and safflower were grown in the rabi (spring) season. Cash crops such as sugar cane, chili peppers, fruit, potatoes, and turmeric were cultivated on only $8 \%$ of the farmed lands. Cereals were grown on $77 \%$ of the Iand and pulses on 12\%. Thus food grain production predominated. of the gross value of the total agricultural produce, $35 \%$ was sold for cash while $17^{\circ}$ was used for in-kind payments. The rest, almost half the production, was kept for home consurption or for use as seed.

In 1942, as can be seen from Table 3 , many of the farming families were joint or extended families in which a number of brothers, and their wives and children would live, cook, and eat under the same roof and cultivate the joint family lands together. This family organization was very well suited to subsistence agriculture because it provided, within the family, the nooded combination of female, male, and child labor necessary for cultivation of a given set of crops.

\section{POST-INDEPEDENCE CHANGES IN TRRTGATION}

Following Independence, improving the productivity of agricultural lands became a major goal of rural development efforts. The government's efforts were directed to boost production through cultivation of more land, enhancing the quality and extent of irrigation, and inducing changes in the cropping pattern so that more cash crops were produced and high yield hybrid seeds were used along with chemical fertilizers and pesticides.

In Sugao, there was little additional land that could be brought under cultivation. However production could be increased by improving irrigation. Reliable year-round irrigation allows the cultivation of several crops a year and of crops that have higher yields and those that sell for higher prices in the market. The total land area of Sugao is 1,090

hectares $(2,691$ acres $)$ of which 881 hectares $(2,175$ acres $)$ are cultivable. Records show that in 1904 about 134 hectares (330 acres) (or 15\%) were classified as irrigated. Most of this was irrigated by eight earthen dams across the village stream, supplemented by a few wells. The earthen dams were washed away annually during the monsoons and were reconstructed communally by those farmers whose land was irrigated by them. Sugao farmers have been using water from the village for irrigation since they first settled in the village. They have developed a complex water distribution system, evolved over the centuries, by which each plot of irrigated land is allocated a certain percentage of the available water.

Recent public investments have improved this delivery of water. In 1965 the state government rebuilt, with permanent masonry construction, four of the eight earthen darns. These need little maintenance. In 1977 government officials claimed that 34 additional acres were irrigated in sugao as a result of this construction, but my field observations did not confirm this. Water supplied by the improved dams was more reliable but remained available only to those who previously had a claim on it. The extra water that was delivered to farmers who owned these lands was often wasted by letting it drain out on the road. The farmers were afraid that if they shared it with their neighbor, then in years when water was not plentiful and there was none to spare, the neighbor would claim a share anyway and some easement laws might allow 
him to assert this claim. As a result, the improvement of traditional irrigation systems in sugao has not increased the amount of irrigated land. This is yet another instance, and the development itterature is replete with such examples, of investments in improved technology and infrastructure not delivering anticipated benefits because the socio-cultural fabric of the community and the unwritten rules by which it is sustained are not understood and accounted for.

Wells are the other form of irrigation in sugao. Most improvements of existing wells have been made, or new ones in sugao have been dug, by individual farmers. Between 1942 and 1977 the number of working wells in sugao increased from 39 to 50. The government introduced a program to make low-interest credit available to land-poor farmers to enable them to construct irrigation wells for their lands. The idea was that these wells would enable farmers to increase their crop production and therefore their earnings. But the few small landholding farmers in sugao who availed themselves of such loans found the maximum amount of the loan insufficient to allow digging wells deep enough to reach water on their plots, and their wells remained dry. These farmers thus found themselves in the unenviable position of having signed away their land as collateral for loans which did not help them to increase their income to pay them off.

Their experience has deterred others in the village, and farmers are extremely reluctant to tie up land as collateral for loans. This has effectively precluded the smaller farmers from taking various loans made available to them under other government schemes. In spite of legislation that makes money-lending at the village level illegal, borrowing at 100\% per annum from local money lenders is still the most important way that villagers, especially the poorer villagers, obtain cash as and when they need it. Generally this is in the form oi small loans which are used to tide over a crisis or emergency. Smaller farmers by and large do not have rnuch access to institutional credit that can be invested in agriculture.
During the major drought in 1972 , the government financed construction of percolation tanks in each village. Percolation tanks are shallow water reservoirs created by building long, low earthen embankments which help dam up surface-draining monsoon waters. The water thus stored percolates slowly into the ground for some four or five months following the rains. Thus the water table for the surrounding areas is higher for a longer time in the year. The village wells are better replenished and can provide irrigation water for two crops. In addition, wet crop such as paddy (rice) can be grown in the percolation tank itself as the water drains away. Some of the wells in sugao within the range of the successfully completed percolation tanks of neighboring vele and Chandak villages increased their water supply considerably, some owners claiming that they had year-round water, whereas before their wells were dry half the year. one of these farmers was so enthusiastic about this improvement that he insisted the author visit his plot to investigate the feasibility of taking some of this additional water, by plastic pipe and gravity-feed, to his other plot some half mile away. Enterprising farmers will rise to the challenge of expanded potential.

The percolation tank for sugao itself was originally not very successful. The earthen embankments gave way during two successive monsoon seasons and were not rebuilt for several years. In 1979, and again in 1982, however, the author observed that the embankment had been reconstructed and reinforced in masonry at the critical pressure point. It was now holding up and the villagers were pleased with its effect, claiming it had improved the water table in the village wells. On previous trips to Sugao, the author had been told by those who had had to give up land for the present tank that there were more suitable sites in sugao which were owned by more powerful farmers who had had enough political strength to get the tanks located elsewhere. No one likes to lose land even if the whole village is to benefit. One finds that often the poorest farmers end up having their lands taken away for projects like the percolation 
tank because they are least able to manipulate the political system to their advantage. This seems to be another characteristic of development efforts: that often the poorest sacrifice scarce resources such as their land for projects that contribute to their community's wellbeing. The sugao percolation tank has clearly improved water availability in the village, but some of the poorer farmers in the community have paid disproportionately for this. In adcition, the main benefit of the percolation tank, raising the water table and increasing the available supply of water in wells within its range, has accrued to the farmers who have wells, generally the better off farmers.

As a result of these governmentinitiated measures, the supply of irrigation water in Sugao has becone more reliable. However, the amount of irrigated land has not increased appreciably and the benefits of greater reliability have therefore accrued largely to those farmers who previously owned irrigated lands, enabling them to switch to crops like sugar canc that have higher market value.

The electrical grid was extended to Sugao in 1964. The extension of electricity to villages can be seen as both a political decision, to illustrate the independent Indian government's concern for the upgrading of village life, and as an economic development strategy. However, most villagers have not opted, or cannot afford, to employ electricity for domestic use and the standard of living in Sugao has not improved in this respect. But most farmers with water sources for their lands have used electricity to power irrigation machinery. Forty-five electric irrigation pumpsets have been installed by farmers on their wells. Thus state infrastructure in electricity has stimulated private investment in irrigation. The replacement of bullock-driven mhots (irrigation machinery to lift water using a leather water bagl by electrically powered pumpsets is pervasive now in Maharashtra. So much so that it is difficult to dissociate the rhythmic background sounds of power motors when one thinks of walks taken in the village Eields. However, this sound, symbolic of rural devel- opments, is also symbolic of increasing inequality in rural areas. For example, those who own enough irrigated lands and can install electrical pumpsets are usually able to buy fertilizers and grow high return, cash crops like sugar cane. Those who do not have the needed resources cannot enter this new arena. At the same time, traditional relationship of barter and payment in foodstuff for labor are atrophying and the poorer people in the village turn increasingly outside the village economy for survival.

\section{CHANGES IN FARMING IN SUGAO BY 1977}

At first glance, farming practices in Sugao do not appear very changed since the 1940's. Traditional tocls and equipment, from the small hand scythes and trowels to the bullock-pulled wooden plough, continue to be used. However, agricultural extension programs in the sugao region, facilitated by the partial increase in water availability, have resulted in a shift of cultivation on wet lands to cash crops, such as sugar cane. sugar cane, a voracious consumer of water and fertilizer, has, with the establisbment of sugar refining factories and the assured market they provide, become one of the most profitable crops in the sugao area. In addition, agricultural extension programs have also encouraged increased cultivation of improved crops such as hybric jowar (millets) or hybrid peanuts, which give higher yields per acre and have shorter maturation periods.

Aggregate data at the district level indicate that the major crops grown in the Satara district are sugar cane (on irrigated lands), jowar (a variety of millet which is the staple food in the area), rice, wheat, lentils (the main source of protein in the local diet), fruits, vegetables, peanuts, chili peppers, and cotton. Crops which are produced in surplus and exported out of the region are coriander, peanuts and peanut oil, turmeric, chili peppers, onions, and garlic. Imported articles include groceries, wheat, cloth, building materials, and medicine. Wholesale trade is concentrated in a few centers such as Satara, 
Lonand, Phaltan, and nearby wai. The economy of Sugao is rather typical of the district and reflects the production pattern described above.

Aggregate statistics on agricultural production are generally based on village level statistics. Theoretically, the talathi keeps village records of crops grown on each separate plot in the village, every year. In practice the village talathi. often creates these records in the comfort of the village office or as in the case of the Sugao talathi, who disliked village life, at his home in wai simply by repeating the same information as was noted the previous year. Thus the official crop record changes very little over the years regardless of what is actually grown.

As a check the author in 1977 did a field survey of crops grown on 177 plots of irrigated land and compared this to a field study of these plots done in 1965. The comparison illustrated the growing monopolization of the good agricultural land by sugar cane and the decrease in crops such as turmeric and sweet potato. It also revealed the increase in doublecropping as a result of better irrigation. A comparison of the 1942 and 1977 cropping pattern in sugao indicates the following significant changes in crops: an increase in areas under cash crops such as sugar cane, peanuts, kharif jowar (which is generaliy a hybrid variety of jowar), rabi jowar (the indigenous variety grown on irrigated lands), broad beans (a black bean called ghevada in this area); and a decline in cultivation of sweet potato and turmeric (which used to be a profitable cash crop for the area but was destroyed in the severe 1971-1972 drought) and a dramatic decline in bajra (millet), once a staple food grain of the village (Table 5).

These shifts have altered the balance of a cultivation cycle that evolved through hundreds of years of small refinements. They have led to a greater dependency on outside inputs such as fertilizer and seeds, have disrupted traditional methods of maintaining the condition of the soil, and have led to a decrease in the variety of foods consumed locally in the village, A typical peasant meal eaten morning or evening in sugao now consists of fresh millet bread with some pickle, a vegetable if any were interspersed and grown among the cash of cereal crops, or a thin dal (soup from lentils) or usal (spiced bean dishes). Often the poorer families will have only the bread for their meal.

By 1977 almost 100 acres of irrigated land, $4.7 \%$ of all agricultural land in sugao, were planted with sugar cane, up from .78 in 1942. Sugar cane needs generous and regular applications of both water and fertilizer, both of which are paid for in cash. Only the richest farmers can therefore afford to take the risk of planting it. It requires over a year to mature, at which time the return on investment in the crop is among the highest for any crop in this region.

In 1977, 15\% of the land was used to grow cash crops while 768 continued to be devoted to production of cereals. However, in the cereals, bajra (one type of millet) was being displaced by ghasar matki (another type that can grow on less fertile soil) which took up $9.4 \%$ of the land, and hybrid jowar which occupied $8.7 \%$ of the land, up from 1.5\% in 1942. This switch in millet type from bajra to ghasar matki is an indication of deterioration in soil quality since bajra is the preferred cereal and farmers will choose to grow it if they can.

As villagers grow more hybrid jowar, they claim they have to buy more animal fodder because the stalks of hybrid jowar are inferior fodder and animals do not like to eat it. The author has observed that in fact hybrid jowar stalks do sell for less than those from country jowar. villagers likewise prefer eating bread made from indigenous varieties rather than the hybrid jowar because they say it doesn't taste as good and doesn't fill one up like the country varieties. They flatly claim that you have to eat twice as much of the bread made from hybrid jowar.

Small changes in cropping pattern are resulting in other such changes, small though they are, in diet and soil quality. For example, sweet potato is a root crop that used to be grown in sugao and was a 
staple food during the rainy season. Harvesting this crop required deep digging and insured proper soil turning which was beneficial to the soil. A decline in cultivation of this crop has meant that soil is no longer deeply turned, i.e., no longer aerated and loosened, allowing the plants to spread their roots further for nutrients, and the quality of the soil has deteriorated. The villagers make some of the traditional, flavorful dishes from sweet potato - like kiise, shredded sweet potatoes sauteed in spices with ground peanuts or kapp, sweet potato slices in gur (a thick syrup of unrefined brown sugar) - less frequently than they used to.

Hybrid jowar has a shorter maturation time than other non-hybrid millets, which it is displacing. It is therefore not possible to intersperse it with pulses. As a result, crop land devoted to pulses has declined from $12 \%$ to $3 \%$. Also, in contrast to grains (wheat, rice, millets), satisfactorily improved strains of lentils are not yet available. Since yields per acre for lentils are low, farmers are switching to other crops. This reauction in cultivation of lentils is unfortunate on two counts. Lentils are the major source of protein in the village diet and reduction in their production means an impoverishment of the peasant's diet. And lentils help to maintain soil quality by fixing nitrogen in the soil. The fact that fewer nitrogen-fixing plants are being grown means that either other alternative fertilizers must be applied or the soil quality will deteriorate further.

one source of soil replenishment is arimal dung. The supply of organic manure in the village has presumably grown with the increase in animal population and in Sugao, unlike other areas of India, this is carefully collected and applied to the land. Night soil is not used as a fertilizer in this region (although some villagers said they had seen it used in some village with fine results and gave indications that they might be persuaded to use it if others did) but people do maintain compost pits in which they put dung and other organic wastes. The decline in pulse cultivation and increased planting of fertilizer-dependent sugar cane and hybrid jowar has resulted in a phenomenal increase in the purchase of inorganic, chemical fertilizers which now require about $25 \%$ of the total farm expenditures. The proportion of cash sales in the gross value of agriculture has increasea from 35 in 1942 to $60 \%$ in 1977 , and this is mainly the result of the increase in sugar cane production.

Hand in hand with this, the cash component of total farm expenditures has also increased from $45 \%$ in 1942 to about 708 in 1977 and the way this is spent has changed significantly. Land revenue and other government-related expenses now account for only $5 \%$ of total farm expenditures, down from 18\% in 1942. Fertilizer now accounts for $25 \%$, with additional outlays going for hybria seeds, potato seeds, pesticides, electricity, and agricultural equipment such as pumpsets.

Although sales of agricultural products and monetized exchanges have increased, the farms are still operated as production-cum-consumption units. Not a single farm specializes in the production of one cash crop such as sugar cane, potatoes, or oilseeds. Farmers grow the foodgrain and fodder they need for personal use and then, if there is land to spare, they raise a cash crop. Most of the farms continue to be operated primarily with family hands, casual labor being hired at peak times, as in 1942 .

\section{FARM SIZE AND ITS EEFECTS ON PRODUCTION}

The average size of farms has been decreasing in sugao. In 1942 only 378 of the farms were below 2.02 hectares (5 adjusted acres; one acre irrigated equals 4 acres non-irrigated). This increased to 448 in 1958 and by 1977 was up to $53 \%$ (Table 3). Thus, there are a growing number of smaller faxmers in the village, an indication that the village population as a whole is poorer. On the other hand, while farmers with 20 acres of more have decreased from $12 \%$ of village families in 1942 to $6 \%$ in 1977, this $6 \%$ continues to control $34 \%$ of the village lands, only slightly less than the 368 it controlled in 1942. Thus, although the number of 
larger farmers is decreasing, those remaining large have gotten bigger and inequality between the rich and poor has increased.

This skewed land distribution among the large and small farmers is illustrated again by the facts that (1) the bottom $40 \%$ of landowing families are controlling decreasing amounts of village lands (10.7\% in 1942 vs. 9.6\% in 1977), and (2) 80 \% of the fanilies control less than $50 \%$ of the village lands $(49.88$ in $1942,46.7 \%$ in 1977).

The smaller farmers in sugao grow mostly cereals, pulses, safflower, or peanuts to be consumed at home. If they own additional land, beyond that required for subsistence, they may grow broad beans or hybrid jowar for cash sales. Most small farmers do not own bullocks. For example, none of the Mahars in Sugao owns bullocks. Although farmers owning less than 2.02 hectares ( 5 acres) of adjusted land constituted $34 \%, 44 \%$, and $53 \%$ of all cultivators in 1942, 1958, and 1977, respectively, they owned only $6 \%, 9 \%$, and $15 \%$ of the bullocks in the village. Most of the bullocks were owned by the largest farmers. Smaller farmers, when they need bullocks to plough their fields, have to hire the services of a farmer who has bullocks to do the work.

Good crop yields depend on ploughing and tilling the land at the critical tines. A bullock owner will first do the bullock work on his own farm and then on the farms of those with whom he has an established labor-sharing arrangement. For example, three farmers each with a pair of bullocks will harness all three teams to a heavy plough and deep-plough each other's holaings. Finally, they will do the work for those paying for the bullock service with cash. Cash alone is not sufficient to procure priority service in the village econony where reciprocal arrangements are stil1 paramount.

Since Sugao, like most villages in this region, is a nuclear village in which houses are closely packed on a central site in the midst of agricultural fields, distances to outlying farms can be as much as three or more miles. The bullock cart is still the major means of transporting goods between the homes and the fields. owning a pair of bullocks and a bullock cart confers status, besides facilitating cultivation by transporting seeds, manure, and pesticides, and hauling of harvested crops.

Smaller farmers' access to credit is poor and they are not capable of bearing financial risks. Experimenting with new crops and agricultural practices is therefore difficult for them. For example, it is well nigh impossible for the small farmer to take up sugar cane cultivation. Even cultivators with 2.02-4.05 hectares (5 to 10 adjusted acres) can affora to put only a half or one acre under sugar cane, assuming they have access to sufficient water. Often they lack the cash needed to buy the required fertilizer. Even if they can manage all this, at harvesting, sugar cane must be processed within hours of its cutting to obtain the peak yield. Ownership or availability of a bullock cart or tractor to transport it immediately to a processing plant is essential.

There were 30 farmers in Sugao who sold sugar cane to the factory in 1977, not one of whom owned less than 5 acres of land; in fact, 24 of the 30 owned more than 5.06 hectares (12.5 acres). Sugar cane cultivation is the de facto monopoly of larger farmers in the village. The increase in cash income for the village as a whole, mostly the result of increased sugar cane cultivation, thus accrues mainly $_{Y}$ to those with larger land holdings.

In Sugao, few farmers have more than .81 hectares (2 acres) of land under sugar cane and only five have $1.6-2.03$ ( 4 or 5 acres). These five have the biggest farms in the village, owning from $6.08-10.13$ hectares (15 to 25 acres) each, including 2.03-5.5 hectares ( 5 to 10 acres) of irrigated lands. They are the power elite in the village. Two of them own gur (unrefined sugar) making units and flour mills, and three of them own tractors. The chairmen of the Village Panchayat and the village cooperative society, and its secretary, are all from these families, and people say that they use these positions to their immediate and extended fami. lies' advantage. 
Like small landowners, women farmers cultivating land by themselves are also relatively disadvantaged, the more so if they own small farms. More and more farmers and agricultural workers in sugao are womon. As Table 3 shows, in 1977 women constituted $65 \%$ of farm workers. The fact that 25 \% of sugao farms are taken care of by women and children alone has not meant that these women have become significantly independert and autonomous in their lifestyles. Generally, they have continued to do the day-to-day work. Some man, either a male relative in sugao or the owner himself returning at critical times, has made all management decisions for their farms.

Villagers of both sexes insist that, when farming is left solely to the women, productivity suffers. various cultural and social factors prevent women from operating the farm optimally. Traditionally women in sugao do not do any of the work involving bullocks. Generally they do not even untie the bullock and take it to graze. When all the men are away, the bullocks are stall-fed until a man returns from the city and takes care of them.

Women are often afraid to guard the crops at night during harvest time or to insure that they get their full share of canal water - a chore that often involves sleeping all night beside the canal. Such tasks are essential if one is to protect one's interests since presently the village farmers act competitively rather than cooperatively. Finally, since men and women do not interact socially in the village, women are cut off from the village grapevine -- a vital source of farming information -- and their farm operations suffer.

It is difficult to estimate how many of the difficulties confronting womer. farmers are "real," i.e., actual lack of ability or strength or an unsafe environment, and how many are, instead, the traditions and expectations of their society. What is important is that at present the whole village, including the women affected, believe that women can't do all the farm work and, therefore, productivity of farms run by women alone suffers.
With increased male migration, and the illegality of tenancy arrangement, more women are farming Sugao lands alone and more of the farm work requiring bullocks is done on hire. This latter trend is also a result of the split-up of the joint family and the consequent fragmentation of land holdings which leaves the new nuclear families with too little land and other assets such as housing and farm sheds, feed, cash reserves, etc., to warrant support and maintenance of bullocks. Villagers say, however, that tilling is not done thoroughly by hired bullocks, that the hired labor does not care how well or everly the land is ploughed or leveled and that the output from the farm decreases. If this is true, and in-the-field observations seem to confirm this, then more and more of the village lands are being less profitably cultivated, The proportion of families that owned land but possessed no bullocks increased in Sugao from $47 \%$ in 1942 to $62 \%$ in 1977. Most of these families get heavy farm work done by hiring bullock services since many village plots are too small to utilize the services of a tractor efficiently.

\section{FARM LABOR}

As mentioned earlier, most of sugao farmers try to do all the farm tasks with their own families ' labor. Hired laborers are usually employed when the work load peaks, e.g., at times of weeding or harvest. Farm tasks are fairly clearly divided between men and women. Most management decisions are made by men, who also do the heavy work such as ploughing, sowing and threshing which needs the help of bullocks. Women perform the day-to-day chores such as weeding, thinning and harvesting.

Although traditionally children have worked on the family farms, the use of child labor has decreased largely because better access to education is being provided and its importance is coming to be increasingly recognized. Whereas $25 \%$ of 7- to 16-year-old children worked in agriculture in 1942, only 108 did so in 1977. More boys than girls were escaping 
the drudgery of farm work by going to school because villagers think that educating a son is an investment, whereas the daughter, after all, is only going to marry and live with her husband's family. In 1942 some 60 s of the children working on the farms were girls; in 1977, almost $80 \%$ were.

With decreasing land/man ratios, more people have been working as agricultural 1.aborers as a primary occupation. In 1942 only $9.5 \%$ of agricultural workers were laborers, but by $1958,11.38$ were and by 1977, 16.6\%. Of these laborers in 1977, 728 were women (Table 1).

Agricultural labor as a secondary occupation for a family had also increased by 1977. The farm households with a second occupation were $398,36 \%$, and $43 \%$ of those with farming as a main occupation for 1942, 1958, and 1977, respectively. of these, those working as agricultural laborers as a second occupation increased from 408 in 1942 to 568 in 1958 to 738 by 1977.

work for acricultural laborers is highly seasonal. At harvest time and during weeding and hoeing there is a labor shortage and farmers coerce those beholden to them to work on their fields first. In: the interim there is little work and laborers go hungry. Available work as agricultural labor varies from 120 to 150 days per year. wages are higher for men than women and there is work for more days of the year for men. Women laborers, therefore, on the average, earn half of what men do. UP to 1979, women's wages were generally two-thirds of men's wages. This difference in pay had existed since at least 1937 when women were paid 19 paisa ( 100 paisa equals 1 rupee) and men 30 paisa. In 1977 women were paid Rs 2.50 and men Rs 4.00. Given that prices rose sixteenfold between 1937 and 1977, there had thus been some decline in the real wages of agricultural workers over the forty-year period. The discrepancy between wages for men and those for women has been increasing as fewer and fewer men are left in the village who are available for casual day labor. In 1982, because of this scarcity of male labor at peak demand periods in the agricultural cycle, men received Rs. 7.00 to Rs. 10.00 (generally Rs. 10.00) per day for farm labor while women received only Rs. 3.00 for a day's work.

Life as an agricultural laborer in sugao is, at best, precarious. In the slack season agricultural laborers often come begging to the doors of larger cultivators asking for odd jobs or advance payments of food. Those farmers who have a grain stock and can make such advances do so to the laborers they trust. They thus always have enough indebted laborers for hired help in-season. A large landholder has many means of ensuring loyalty from agricultural laborers. He can lend money to a worker at a time of crisis or he can hire one of the laborer's family members to work in his flour mill, gur factory, or other enterprise. He may have a lien on the laborer's land. In some instances, he can be a reliable and fair employer whom the laborers like to work for. In some instances he may not be but still the laborers must work for him, if only to pay off the debts they have incurred to him in times past. The small and marginal farmers, on the other hand, have little extra leverage in recruiting laborers in the peak season and therefore often have difficulties harvesting their crops on time.

Apart from agricultural labor hired on a daily basis, there is a system of bonded labor or attached labor that exists to varying degrees in different parts of India. An attached laborer contracts-himself for a year's work to a family in return for a predetermined annual wage of cash and kind payments. No limits are set to the number of hours or kinds of work he must perform; consequently this system can become extremely exploitative. There are very few such attached laborers in Sugao. The two attached laborers the author observed closely and got to know well in Sugao belonged to poor sheep-herding families from a village to the east of Sugdo located in the drought-prone area of the district. They worked for a woman who was a hard taskmaster and noted for her acid tongue. They had long, 12- to 14hour workdays and were often fed left-over food and bread that was specially made for 
them from inferior, cheaper grain. They worked twelve hours, seven days a week. In return, they got 5 to 10 days of vacation, food, clothes (1 T-shirt, 2 shirts, 1 pair of sandals, and 1 pajama) and a cash payment of ks 500. At prices current in 1977 , this amounted to $\$ 161$ per year. An attached laborer is in effect a servant. His workload and material conditions of life depend completely on the inclination of his master. This practice of attached or bonded labor is not common in sugao and by 1982, there were almost no attached laborers in the village. However, this practice is more prevalent in other parts of the state, such as the adivasi tribal areas of Maharashtra, where it is structured to exploit the poor to the maximum.

\section{MONETIZATION OF THE SUGAO ECONOMY}

of all the farming families in the village in $1977,31 \%$ (25\% of all the families in sugao) claimed to be self-sufficient, i.e., producing all their basic food requirements. Slightly less than half, $47 \%$ ( $38 \%$ of total families) had deficits of $1-6$ months and $22 \%$ (18\% of total families) had even larger deficits of 6 to 12 months. Farms over 1.4 hectares ( 3.5 acres) were mostly setfsufficient and the majority of farms deficient for 6-12 months were smaller than 1.4 hectares ( 3.5 acres).

Almost 408 of all the families in the village who were buying food were buying it from the ration shop. The government's establishment of ration shops in villages has helped some of the poorer families to survive. However, the switch to greater cash transactions leading to fewer, inkind, grain payments and the reduced availability of food grains in the village due to lowered production of grains as a result of allocation of land for sugar cane cultivation helped to force these families to buy grains in the first place.

Most of the customers at the ration shops are the farmers who are smaller landowners. They have a greater need to buy food grains than before because, formerly, if they worked as agriculturai laborers, they used to be paid in kind, usually in food grains. Nowadays, the larger farmer often prefers to pay for farm labor in cash, because he can afford to store the grain and sell when prices are high. He can thus get a greater price per unit of grain than he can for using it to pay his laborers. By contrast, until recently wage payments in cash for men and women remained fairly constant, increasing only slowly, lagging behind market prices so that the larger farmer comes out ahead paying cash to his workers. Although the pay for male laboxers had increased by 1982, the pay for women was quite low and this is significant given that women constitute over $70 \%$ of those whose primary work is agricultural labor. This situation will change only when agricultural labor is organized and can demand wages in kecping with the general rise in prices. Currently the laborer can just maintain himself only because he obtains food sold at controlled prices in the ration shop.

Food sold in these shops cone from centers such as wai, where grain is collected from the surrounding region and distributed to the ration shops. The grain so collected is often of an inferior variety because it is obtained from famers, by a levy, at a controlled price. Farmers tend to grow hybrid varieties, which give higher yields but are less relished, to meet this quota. The rich farmers usually try to grow enough food grains of the preferred indigenous variety for personal consumption and the farmers buying from the ration shop are quite firm in stating that they would rather eat the indigenous varieties.

often the poorest in the village do not have sufficient cash to buy the minimum quantities sold in the ration shop. For them the day's work pays for that night's meal. These families are forced to buy their necessities daily in the local shops in tiny amounts. Even salt, one of the cheapest ingredients, is bought in miniscule quantities. These very poorest - 17\% of Sugao families - whose daily existence is hand to mouth never buy at the ration shop. Ration shops do not give food stuffs on credit. This is a problem on nights when the laborer has 
found no work and has no money but must cook a meal. Nor do they deal in the tiny volumes these people must buy. Therefore the poor must buy at the non-ration stores, paying two to three tines the price they would if they purchased food in larger quantities. Currently, therefore, the poorest pay the highest prices for generally inferior foodstuffs.

Another $17 \%$ of the population which must buy foodstuffs do so in larger quantities (sacks of grain, gallon tins of oil, etc.) either in the village or at wai where one gets the best values for one's money. Naturally this is the preferred way of making up food deficits and those families which receive money remittances from Bombay are often able to make such purchases.

of the families that produced surpluses in 1977 those that sold it 1ocally in sugao tended to own less land -2.03-5.06 hectares (5 to 12.5 acres) than those who sold at wai. The rine families with holdings of 5.06-8.1 hectares $(12.5$ to 20 acres), a mere $2 \%$ of all cultivators, sold their produce as far away as Poona or Bombay where the prices are highest. smaller farmers, with less to sell, cannot afford to travel very far to seek a better price. Only the larger cultivators can manage the market to their advantage and sell high. Thus in a cash crop economy, where monetary transactions predominate, the subsistence farmer fares badly and is progressively being squeezed out of his occupation as a cultivator.

In 1977 about $75 \%$ of the total consumer needs in Sugao were cash purchases. At least two factors explain this high a figure. Families lacked sufficient land or livestock to meet theix total requirements for foodgrains, milk, and vegetables. Also, there has been a shift in the village using city-made or processed products. This shift has had an adverse impact on the village economy. Cooking ojl serves as an example. Oil that comes from outside sugao is cheaper than locally pressed oil from village-grown oilseeds and therefore has supplanted the local product. The price difference stems from the fact that the new hybrid varieties of peanuts now cultivated in the village require higher pressures for oil extraction. The oil press in the city is larger and more efficient at this extraction. In addition, the hybrid varieties of peanuts have been developed for eating rather than oil production, so villagers cultivated and sold them for this purpose and bought the more refined cooking oil from the city. But the villager lost in this transaction because the refined oil is less nutritious than the unrefined local product. In addition, when oil used to be pressed locally in small oil presses in Sugao, the villager kept the leftover peanut cake, an extremely nutritious cattle food to feed to their animals. The villager forfeits this byproduct when he buys oil from the shop.

Sugar consumption has undergone a similar shift. More villagers bought refined sugar produced in large factories in the towns, which is more expensive and less nutritious than the locally produced gur. Increasingly, products of the city have made inroads into the village market. Plastic footware, soap, cosmetics, medicine, tea (the consumption of which has jumped tremendously in the last thirty years), metal ware, and tobacco have all supplanted village products. The value of manufactured goods purchased by sugao people almost doubled in real terms between 1942 and 1977 .

Cash, then, has become more important. But in agriculture only the larger farmers have been able to tap into the cash crop economy and profit effectively. The land-poor and landless are having difficulties in just coping. They cannot turn to work in local non-agricultural activities for extra income because of a vicious circle that has been established. The non-agricultural sector in rural economies has traditionally been quite smal1, and as villagers have increasingly bought city products, village-level production has shrurk even further. Even fewer opportunities now exist to earn a living in non-agricultural endeavors in the village while the amount of cash needed to buy agricultural inputs and consumer goods has continued to rise. 
It is clear that agricultural development policy must take a new direction if the cycle described in the preceding pages is to be broken. If the current direction of development continues, the village will continue to become increasingly dependent on the city and the small subsistence farmer will gradually be squeezed out of the village economy but find no niche to fit into in the urban economy.

From a development perspective it seems that to "improve agriculture" is not merely to increase the market value of agricuitural products grown but to make more food available for people and improve the nutritional content and diversity of their diets. Currently sugao people are eating less protein, as they grow fewer pulses; are reducing the variety of crops they raise for personal consumption; and are paying for this with monotony in their diet, in an effort to maximize their production of cash crops. A better goal of agricultural development in sugao might be to produce sufficient food to feed the entire village and raise nutritional levels. An assessment of changes in agriculture should measure their usefulness for improving living standards and nutrition. The objective should be not the modernization and monetization of agriculture for better production of cash crops but for improvement in the food available for consumption to rural as well as urban people.

The sugao experience is rather typical of observations that have been made in other parts of rural India. After some 40 vears of planned intervention in agricultural development, it seems clear that monetization of the village economy can adversely affect the position of poorer farmers, of women, and others who have traditionally had limited resources in the viliage. For a self-reliant rural society to evolve through planning, there must be a shift in the focus of development efforts from agricultural productivity per se, to strategies for attaining self-sustaining rural development. These strategies labeled "Rottom-Up," "grass-roots" strategies in the development literature are ones that have the transformation of rural institutional structures as their objective - transformations that lead to a more egalitarian, better quality life for all. Unless this shift in emphasis is embraced, the prognosis for development that improves the life of the poor in. rural parts of India seems bleak.

\section{NOTES AND REFERENCES}

${ }^{1}$ Data for this paper were arawr from several surveys executed by the Gokhale Institute of Politics and Economics, Poona, since 1936, particularly two comprehensive socio-economic full census surveys in 1942-43 and 1958-59. Components of these were repeated by the author in a full census survey of village residents in 1976-77 during an 18-month residence and field investigation of the village. A purposive sample of Bombay migrants was intensively interviewed by the author during the following threemonth period. The study was augmented by observations and information collected by the author during two subsequent visits both to the village and to Bombay to interview sugao migrants in the summer of 1979 and December-January, 1981-82.

2 The ryotwari system of land, consisting of individual peasant proprietors who paid land taxes directly to the state, was operative in this part of Maharashtra. For a detailed description of the traditional land-ownership system and socioeconomic organization that controlled access to land, see Hemalata C. Dandekar, 1978, Rural Development: Lessons from a Village in Deccan Maharashtra, India, UCLA, Ph.D. dissertation, Chs. 4 \& 5 , pp. $78-157$.

3 Figures calculated from Farm Business Surveys by the Gokhale Institute of Politics and Economics executed in 1938.

4 The mawal region is a belt about 10 to 20 miles wide immediately to the east of the sahyadri range of hills. It has only moderate rainfall, but the rain is well distributed over the year and allows for reliable, rainfed agricultural cultivation of diverse crops. 
5 For a case study that refers to the attrition of in-kind payments in two villages in Maharashtra, one of which is Sugao, see Hemalata C. Dandekar and Sulabha Brahme "Role of Rural Industries in Rural Development," in R.F. Misra and K.V. Sundaram, 1979, Rural Area Development, New Delhi: sterling Publishers, 1979. pp. 122-143.

${ }^{6}$ For a description of the various phases of rural development planning in the Indian Plans, see Hemalata $C$. Dandekar, op. cit. 1978, Chapter 1, pP. 7-31.

7 See Sulabha Brahme, "Role of Peasant Economy in Capitalist Development: Case
Study of a Maharashtra Village," Gokhale Institute of Politics and Economics, 1976. Unpublished manuscript.

8 Detailed case studies of women in Sugao, including women farmers were compiled by the author during residence in sugao in 1976-77, 1979, and 1981-82. The author is in the process of completing a book on the impact of development on rural women in India.

9 For a comparison of rural industries in one small (Sugao) and one large village in Maharashtra, see Hemalata C. Dandekar and Sulabha Brahme, in R.P. Misra and K.V. Sundaram, op. cit., 1979.

(Dandekar Tables 1-5 follow on pp. 28-30).

TABLE 1: MAIN OCCUPATION OF SUGAO WOHERS

\begin{tabular}{|c|c|c|c|c|c|c|c|c|c|}
\hline \multirow[t]{2}{*}{ Cccupation } & \multicolumn{2}{|r|}{1942} & \multicolumn{4}{|c|}{1958} & \multicolumn{3}{|c|}{1977} \\
\hline & Male & Female (t) & Total (S) & Male & Female (2) & Total (n) & Male & Female(a) & Total (M) \\
\hline $\begin{array}{l}\text { Cultivation } \\
\text { Agricultural }\end{array}$ & 230 & $355(60.0)$ & $593(76.5)$ & 279 & $483(63.0)$ & $762\langle 75.7\}$ & 342 & $616(64.0)$ & $95 \mathrm{~B}(73.4)$ \\
\hline Labor & 16 & $48(75.0)$ & 64 (9.5) & 40 & $59(50.0)$ & $99(11.3)$ & 54 & $140(72.0)$ & $194(16.6)$ \\
\hline Cattle Herding & 11 & 3 & & 8 & 1 & & 4 & 4 & \\
\hline Attached Farm & 2 & - & & 5 & - & & 5 & - & \\
\hline Sub-Total & 267 & $406(60.0)$ & $673(\theta \bar{b} .0)$ & 332 & $543(62,0)$ & $075 \quad(67.0)$ & 405 & $760\langle 65.0)$ & $1165(90.0)$ \\
\hline
\end{tabular}

\begin{tabular}{lrr} 
Prosucticn & & \\
Artisan & 36 & 23 \\
Service & & \\
Artisan & 23 & 10 \\
Trede & 5 & 3 \\
Constiuctiun & 5 & - \\
Services & 3 & - \\
Other & - & - \\
\hline
\end{tabular}

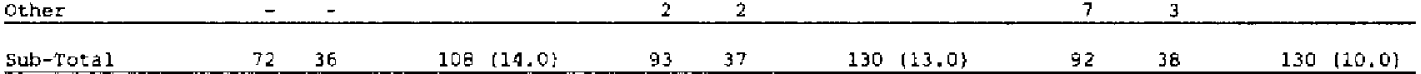

Grand rotal

(Number) of

Earners in the

village $339 \quad 442 \quad 781$

$35 \quad 21$

$23 \quad 19$

Earners working

cutside the

village

as a of total

earners in Sugas

and cutside

1967

21

217

$\begin{array}{rr}7 & 3 \\ 14 & 3 \\ 14 & 1\end{array}$

19

Curce. Data for tables -4 from full cengug surveys of householis in sugao in $1942-43$ and $1959-59$ by the Gokale Institute of politics and Economics, Poone, and a similar survey of the village by the author in $1976-77$. 
TAELE 2: FAMILT TYPE IN SUGAO

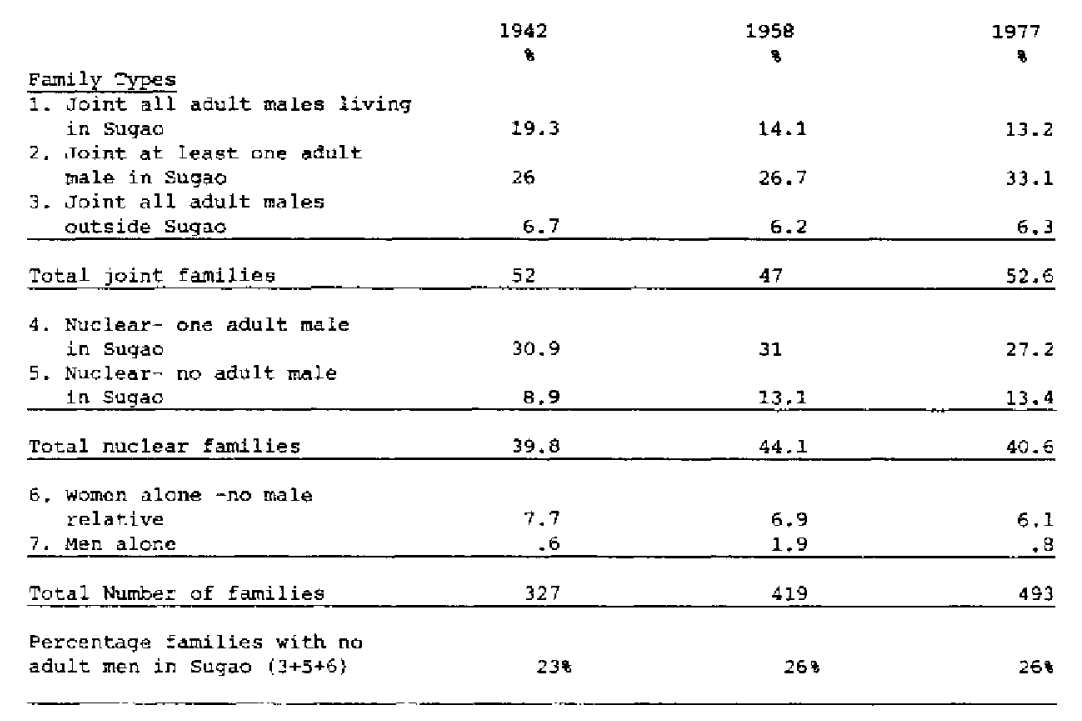

TABLE 3: LAND DISTRIBUTION IK SUGAO EY SIZE OF FARM

\begin{tabular}{|c|c|c|c|c|c|c|c|c|c|c|c|c|}
\hline \multirow[b]{2}{*}{ Land Foldings ${ }^{1}$} & \multirow[b]{2}{*}{ No. of } & \multicolumn{3}{|c|}{1942} & \multicolumn{4}{|c|}{1958} & \multicolumn{4}{|c|}{1977} \\
\hline & & Families & Land re & & No. of & fantiles & Land $\mathrm{n}$ & neid & No. of & Eamilieg & Land hel & $1 d$ \\
\hline Jp to 1.0 & 26 & & 13.50 & & 31 & & 16.60 & & 35 & & 77.20 & \\
\hline 1.5 & 10 & & 12.10 & & 22 & & 24.90 & & 34 & & 38.36 & \\
\hline 2.5 & 25 & & 49.72 & & 28 & & 53.46 & & 54 & & 102,06 & \\
\hline 3.5 & 27 & & 82.92 & & 36 & & 103.16 & & 47 & & 149.84 & \\
\hline 5.0 & 22 & 37 & 94.70 & 9 & 40 & 44 & 168.56 & 12 & 43 & 5.3 & 183.20 & 16 \\
\hline 7.5 & 42 & & 269.10 & & 46 & & 284.56 & & 52 & & 369.64 & \\
\hline 10.0 & 4. & 28 & 371.94 & 22 & 53 & 28 & 456.22 & 24 & 42. & 24 & .359 .70 & 21 \\
\hline " 12,5 & $2 E$ & & 284.94 & & 31 & & 343.32 & & 33 & & 368.42 & \\
\hline$=20.0$ & 4 & 23 & 664.50 & 33 & 35. & 18 & 551.56 & $2 \mathrm{E}$ & 34 & 17 & 541.66 & 29 \\
\hline over 20.0 & 36 & 12 & 1032.40 & 36 & 37 & 10 & 1119.86 & 36 & 25 & 5 & 1047.83 & 34 \\
\hline $\operatorname{cotal}$ & 30 & & 2875.82 & & 359 & & 3122.20 & & 399 & & 3117.91 & \\
\hline Landidegs & $2 e$ & 6 & --- & & 60 & & --- & & 94 & & 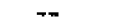 & \\
\hline
\end{tabular}

1. Land holding in adjusted acres. One acre irrigated land equals four acres non-irrigated.

2. Land heli in acres. 
TABLE 4: CROF PATFERN IN SUGBO

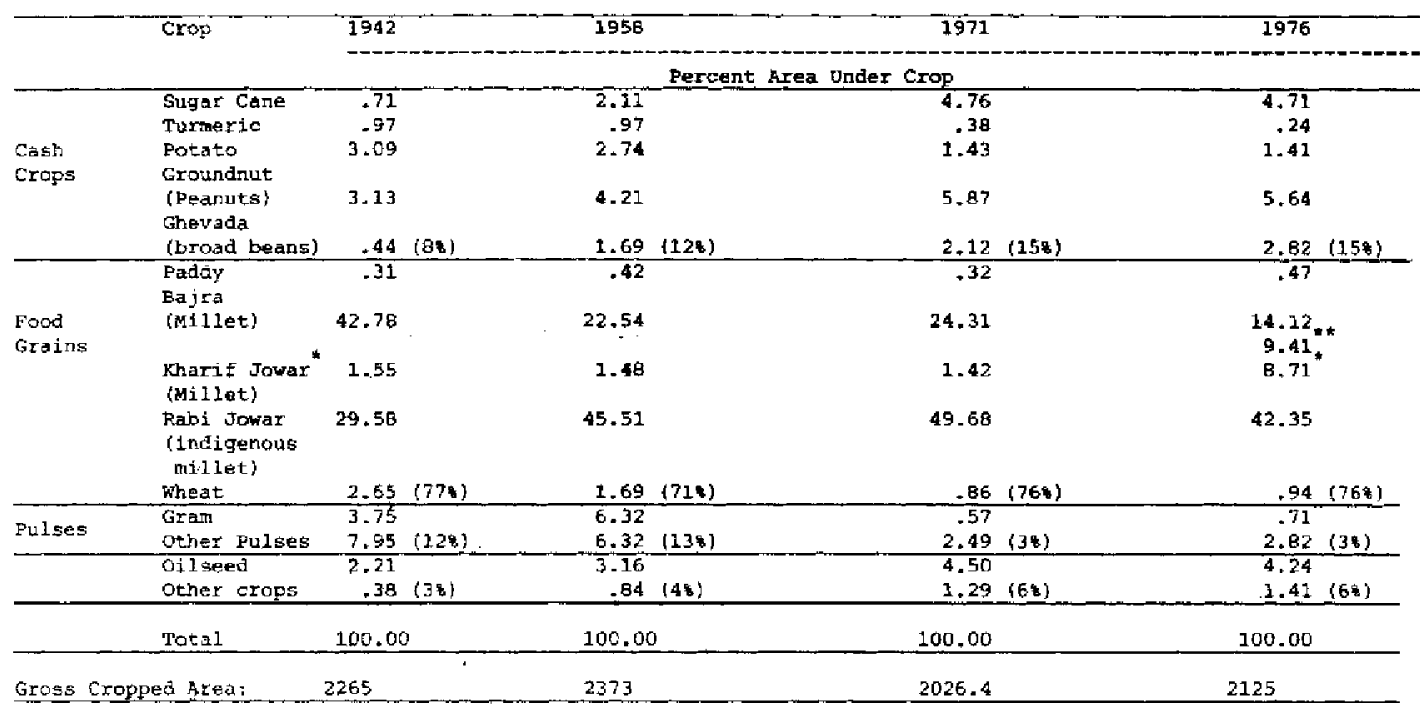

* Horid jowar which is currently predominantly a kharif crop.

Ghasar matki which is an inferior jowas.

TAELE 5: COMPARISON OE CROP PATTEFN IN 1965 AND 1976 EOR 177 PEOTS BY THE MAHADEV DAM

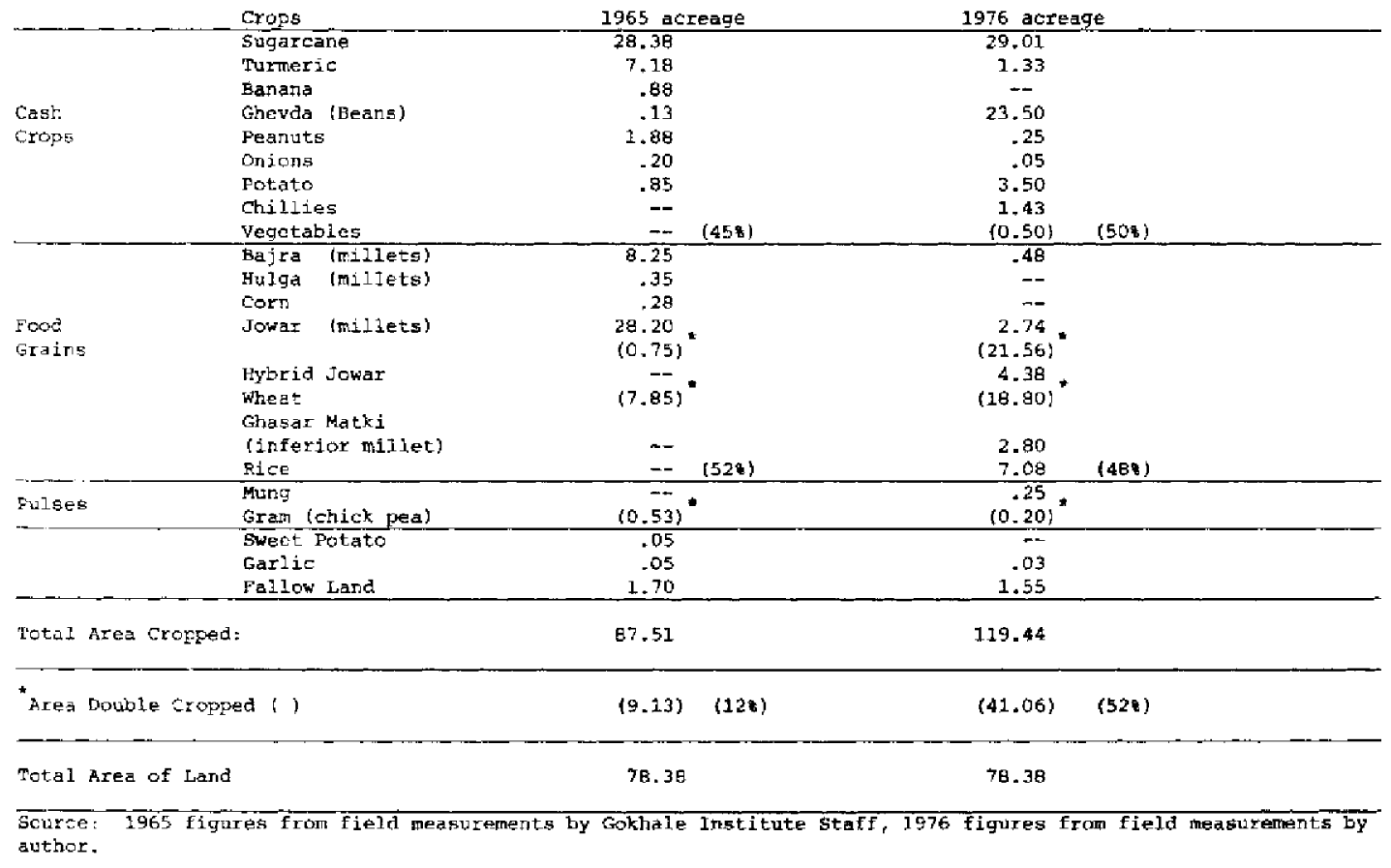

